\title{
O Calendário Republicano e a Festa Cívica do Descobrimento do Brasil em 1890: versões de história e militância positivista
}

Elisabete da Costa Leal ${ }^{*}$

\section{Resumo:}

O texto aborda como os membros da Igreja Positivista do Brasil - IPB -, e alguns políticos aliados, se envolveram na proposição do Decreto 155-B de 14 de janeiro de 1890, que estabeleceu o calendário republicano de feriados oficiais, e como se empenharam para consolidá-lo na cultura política da Primeira República. Exemplificase tal movimento por meio da análise da festa de 3 de maio de 1890, decretada como o feriado em celebração do descobrimento do Brasil.

Palavras-chave: Primeira República, Positivismo, Festas Cívicas.

A República no Brasil foi proclamada de forma abrupta, causando surpresa até mesmo entre alguns republicanos. No entanto, dos grupos envolvidos no "movimento" republicano, os membros do Centro Positivista e da Igreja Positivista do Brasil ${ }^{1}$ — IPB — já estavam bem preparados com propostas objetivas de organização do novo regime. Isto se revela no modelo da bandeira, no decreto de separação entre Igreja e Estado, na forma de tratamento na correspondência oficial usando a expressão "Saúde e Fraternidade" e no decreto do calendário cívico, todos propostos ao Governo Provisório logo depois da implementação do regime. Tudo sugere que estas propostas já estavam redigidas antes de proclamada a República.

Dois meses após a proclamação, decretou-se o calendário de festas ou feriados cívicos. Um levantamento nos periódicos publicados no Rio de Janeiro no mês de janeiro de 1890 revela que tal decreto passou despercebido. ${ }^{2}$ Os outros decretos que também definiram uma simbologia republicana e que marcaram a experimentação cívica dos brasileiros com o novo regime mobilizaram mais a atenção dos jornais, como o da bandeira e o do hino nacional, como mostrou Carvalho (1990, p.109). À medida que as festas cívicas ocorriam ao longo do primeiro ano republicano, questionamentos sobre a escolha das datas do calendário entravam no debate. A terceira data despertou 
curiosidade; o 3 de maio comemorava a descoberta do Brasil, que para todos havia ocorrido em 22 de abril. Essa controvérsia inaugurou outras a respeito do calendário, gerando resistências a algumas comemorações e tentativas de alterar a lista das datas oficiais, o que acabou acontecendo na década de 1920, quando os positivistas não tinham mais poder mobilizatório em setores do governo e da Câmara Federal suficiente para impedir que o calendário fosse modificado.

Nos primeiros anos republicanos, observa-se um crescente desejo de participação política dos brasileiros, somado a uma explosão do sentimento cívico/patriótico. Abundam as formas de manifestação política organizada representativa de diferentes grupos, que produziam imagens de si e de seus homenageados. A festa cívica era uma das formas de dar visibilidade a imagens e promover uma educação visual republicana. ${ }^{3}$ Planejar uma festa cívica e definir que imagens seriam mostradas ou não, e possuir uma coleção de imagens para isso, fazia parte do jogo e disputa políticos e de poder que atravessavam a sociedade.

A bibliografia sobre as festas cívicas republicanas é escassa. ${ }^{4} \mathrm{Da}$ mesma forma, há uma carência de estudos sobre o significado e a implementação do calendário de festas oficiais na I República, bem como sobre os diversos grupos em disputa para sua consolidação cívico-cultural. Além do estudo de Oliveira sobre como as festas oficiais republicanas ajudaram a dar um sentido de identidade à nação brasileira (Oliveira, 1989, p.172-89), existem trabalhos sobre as comemorações da Independência na Bahia, que identificam a mudança no formato e significado festivo do 2 de julho a partir da República, o que abalou e recriou suas tradições, além de alterar o estrato social que se apropriava da festa (Albuquerque, 1999; Kraay, 2003, p.51-81), e sobre as marchas cívicas em Porto Alegre, envolvendo a recepção do regime republicano por diversos grupos organizados, demonstrando um desejo de participação política e de vivência da cidadania republicana (Pacheco, 2001).

Este texto visa analisar a contribuição de um grupo específico de republicanos — os membros e aliados da Igreja Positivista do Brasil - no desenho do calendário de festas oficiais e no esforço de torná-lo conhecido e incorporado na cultura política que se ensaiava nos primeiros anos do regime. É necessário compreender o significado do culto público positivista comteano, pois não podemos esquecer que os proponentes do calendário oficial eram positivistas ortodoxos. O empenho desse grupo ficou evidente 
na realização da festa cívica de 3 de maio de 1890, a festa do descobrimento do Brasil, discutida abaixo.

\section{O culto positivista - política e emoção}

A Religião da Humanidade criada por Comte era uma religião da História e um culto aos mortos, no sentido memorial. Era composta por um culto privado e um culto público. O primeiro ocorria no espaço doméstico e era voltado para a lembrança dos familiares mortos, estimulando diariamente a rememoração da história dos antepassados e sua transmissão. O culto público ou coletivo ocorria nos templos positivistas, era destinado a celebrar a Humanidade e seu passado e dirigido pelos sacerdotes (filósofos).

Os positivistas também estimulavam as atividades cívicas, fora dos templos. As comemorações públicas ou culturais, exaltando os grandes homens que contribuíram positivamente para a história da humanidade, a construção de prédios públicos dedicados a fins culturais e a confecção de monumentos públicos, estátuas, bustos, bandeiras, mausoléus fúnebres, faziam parte da estratégia de ação religiosa com fins políticos, fora dos templos. "O espaço inteiro da cidade será a comemoração, a adoração da Humanidade pela nominação de ruas, tecendo no espaço o Calendário Positivista" (Grange, 1996, p.402). A vida pública e coletiva, que estimulasse a lembrança do passado da Pátria e as diferentes formas de celebrá-lo, integrava também o culto da Humanidade. Essa proposta de vida social e cultural visava criar uma unidade simbólica entre os cidadãos. Era o conhecimento do passado, da história, que uniria os homens, e a arte era um dos caminhos para isto.

É a arte, que não é arte somente no sentido da estética, que permite dar uma identidade imaginária ao coletivo. Esta identidade se expressa aos olhos de todos de uma maneira indireta em um grande número de formas de expressão: estátuas e monumentos, nomes de ruas e obras de arte. (Grange, 2000, p.237)

Os positivistas brasileiros procuraram implementar esse culto - doméstico e no Templo, e também o culto pátrio, estimulando a realização de celebrações cívicas e se esforçando para definir um panteão de heróis, não somente de brasileiros. Propor os decretos da bandeira e do calendário, sugerir um projeto de Constituição republicana, publicar artigos nos jornais cobrando atitudes do governo faziam parte da vivência religiosa do positivista. Intervir politicamente e influenciar a opinião pública eram 
estratégias de ação religiosa que, no Brasil, com uma República recém-nascida, encontravam um campo promissor. Aqui cabe um alerta: quando se faz referência a essas tentativas dos positivistas ortodoxos brasileiros de implementar um culto cívico no Brasil, não se está afirmando que, em termos oficiais, a Religião da Humanidade tenha sido assumida, tampouco o calendário positivista, mas que esse grupo de positivistas se esforçou para influenciar o culto cívico republicano brasileiro, pois isso fazia parte de suas obrigações doutrinárias. Na verdade, a Religião da Humanidade foi assumida e vivenciada apenas por pouco mais de uma centena de brasileiros. ${ }^{5}$

O empenho desse grupo em intervir nos rumos do novo regime republicano se baseava no entendimento de que o Brasil estava ávido por uma solução civilizatória, na qual as celebrações cívicas teriam papel fundamental, e o positivismo, uma religião científica e política, oferecia isso. A IPB seguiu os preceitos comteanos do uso de obras de arte em celebrações religiosas e cívicas e investiu em intervenções mais políticas, tentando influenciar legislativamente o país e emplacar um panteão nacional. Miguel Lemos afirmou: "O Positivismo é sobretudo uma religião cívica” (Lemos, 1981, p.29). Essa visão de positivismo mostra a estratégia adotada pelos líderes da IPB, voltada para grupos mais escolarizados, como os militares.

A estratégia de ação social de Comte e dos positivistas brasileiros foi distinta quanto ao público envolvido: o primeiro se dedicou à educação operária ${ }^{6}$, e os brasileiros se voltaram à cooptação de grupos mais intelectualizados, mas os mecanismos de sensibilização cívica via emprego de imagens e ritualizações foram os mesmos. "Se a doutrina lhes dava o conteúdo da simbologia, a concepção estratégica impulsionava-os para a ação com maior urgência do que a sentida pelos positivistas franceses, ou europeus em geral, mesmo os de convicção comteana" (Carvalho, 1990, p.139).

A Revolução de 1848, que restabeleceu a República na França, revelou-se para Comte como a grande possibilidade de implantação de um modelo político que aliasse “a lógica dos sentimentos e dos símbolos à trama do discurso racional” (Larizza in Trindade, 1999, p.51). A República para Comte se configurou como grande portadora de esperança da regeneração social que ele mesmo vinha pregando, tornando possível a coalizão entre filósofos e proletários. Tal regeneração se daria pela implementação de um projeto filosófico/político via sentimentos e símbolos: uma religião política. No Brasil, a coalizão social foi outra, mas a estratégia a mesma. Aliás, Comte forneceu a 
fórmula de ação adotada pelos brasileiros: elenco de tipos ideais (heróis) + produção, com exageros, de suas imagens + sua contemplação = emoções.

Comte instituiu o uso de imagens e ritos que deveriam se transformar numa forma de culto social, dando uma dimensão imaginária à vida cívica, tendo por âncora o passado. As festas católicas e as festas públicas revolucionárias foram modelos para Comte, ambas se utilizando fartamente de imagens e de evocações da história. Sua proposição era uma síntese da alegoria republicana, com a estatuária, e da simbologia cristã, com a pintura. Ambas as formas de expressão artística tiveram a capacidade de ligar o passado ao presente. "Comte esperava sintetizar duas concepções opostas da mediação social e da figuração artística que se reencontrarão e funcionarão espontaneamente: a imagem cristã e a estátua alegórica republicana, a missa e a festa" (Grange, 2000, p.244).

O estímulo a uma religiosidade civil, que teve por inspiradores Rousseau e Comte, mas também Saint-Simon e Voltaire, deu base às atividades que homenageavam os grandes homens. A heroicização de homens comuns - nem reis, nem santos demonstrava o ideal liberal e laico que imperava nos oitocentos (Agulhon, s/d., p.143). Esse novo culto requeria liturgias em que o cidadão era agente político, ao mesmo tempo espectador e ator na festividade cívica.

Catroga, ao analisar tal fenômeno festivo em Portugal a partir de final dos anos 1970 do século XIX, entendeu-o como ritualizações da História ou lições móveis de História (Catroga, 1998, p.223). Tais práticas descendiam, segundo ele, das festas cívicas inauguradas na Revolução Francesa e de um diminuto culto da humanidade, porém não ortodoxo, popularizadas também no movimento socialista português.

Os positivistas brasileiros também perceberam o poder de mobilização emocional que as celebrações cívicas continham. Carvalho chamou a atenção ao fato de os positivistas da Igreja terem se dedicado de forma ativa e beligerante, por meio de textos, rituais e símbolos cívicos, a tornar a República aceita e amada pela população (Carvalho, 1990, p.129). Sua observação se reforça quando se analisa o esforço da IPB para que o governo implementasse o novo calendário de festas nacionais.

\section{O Calendário Republicano de Festas Nacionais}

Segundo Teixeira Mendes, o texto original do decreto do calendário era seu, redigido a pedido de Demétrio Ribeiro, que suprimiu algumas datas e ampliou a 
comemoração do 14 de julho, que no texto original era exclusiva à Revolução Francesa. ${ }^{7}$ Dos membros do Governo Provisório que assinaram o decreto, Demétrio Ribeiro, que o propôs, e Benjamin Constant eram os que tinham maior compreensão do positivismo. Os demais assinantes do decreto, Deodoro da Fonseca, Ruy Barbosa, Quintino Bocayuva, Eduardo Wandenkolk, Aristides Lobo e Campos Salles, ou não perceberam seu tom positivista, ou não se importaram com isso, ou apenas não tinham uma outra proposta de calendário. Não se sabe se foi divulgado que o texto original era de Teixeira Mendes.

Benjamin Constant e Demétrio Ribeiro foram os principais contatos da IPB no recém instalado governo e os que apresentaram propostas de decreto com teor mais positivista. Ao ler as publicações da IPB em que seus líderes relatam essas conquistas políticas para o positivismo, observa-se que facilmente eles identificavam as propostas de decretos como suas. Mas o fato é que ambos os Ministros eram positivistas, independentes da Igreja, e qualquer organização política que propusessem convergiria para soluções positivistas. De Demétrio, principalmente, os líderes positivistas se orgulhavam dizendo que "ele éra filho escluzivo de nóssa propaganda e chegava ao poder com o programa pozitivista na mão" (Lemos, 1981). Mas logo Demétrio deixaria o Governo Provisório e romperia com a IPB.

A proposição do decreto é totalmente em termos positivistas, mas não é um Calendário Positivista tal qual o proposto por Comte e adotado internamente pela IPB. ${ }^{8}$ Com exceção do $1^{\circ}$ de janeiro, as demais datas do calendário positivista e o republicano brasileiro não coincidiam. Assim foram decretadas, em 14 de janeiro de 1890, as festas nacionais:

- $1^{\mathrm{o}}$ de janeiro, comemoração da fraternidade universal;

- 21 de abril, comemoração dos precursores da Independência brasileira, resumidos em Tiradentes;

- 03 de maio, comemoração da descoberta do Brasil;

- 13 de maio, comemoração da fraternidade dos brasileiros;

- 14 de julho, comemoração da República, da liberdade e da independência dos povos americanos;

- 07 de setembro, comemoração da independência do Brasil;

- 12 de outubro, comemoração da descoberta da América; 
- 02 de novembro, comemoração geral dos mortos;

- 15 de novembro, comemoração da Pátria brasileira.

Em nome do sentimento de fraternidade universal, da continuidade $\mathrm{e}$ solidariedade das gerações humanas, da ligação pátria com outros povos, o calendário era composto por datas que não eram exclusivas à história brasileira. Ele obedecia a uma lógica histórica que ligava a história brasileira à história ocidental, iniciando com a descoberta do Brasil, em 3 de maio, e culminando com a comemoração da Pátria brasileira, consolidada com a República, em 15 de novembro. Essa última data do calendário encerrava o ano, mas simbolicamente iniciava um novo ciclo da história nacional. Ferreira Neto observou que o decreto ordenava o passado brasileiro através de um calendário que comemorava as origens da República. "Espalhadas pelo ano, ..., estão cronologicamente alinhadas as etapas fundamentais de uma crescente consciência da Nação em si e para si” (Ferreira Neto, 1989, p.68).

Decretado o calendário, logo os políticos não positivistas e membros do clero católico se rebelaram, pois circulava a notícia nos jornais europeus que a recémRepública brasileira havia adotado o calendário positivista de Comte. O Ministro da Fazenda, Rui Barbosa, que assinara o decreto, ao desmentir o fato na imprensa européia, chamou a idéia de absurda, ofendendo os positivistas. $\mathrm{O}$ fato resultou na publicação no Rio de Janeiro e em Paris do folheto O Calendário Positivista e o sr. Ministro da Fazenda (Lemos, 1890). Tal debate não apareceu na imprensa brasileira, mas isso não quer dizer que os católicos não estivessem atentos ao calendário, já que os feriados oficiais davam grande visibilidade à separação entre Igreja e Estado, assumida pelo novo regime. Certamente os católicos perceberam que nenhum feriado religioso fora decretado no calendário. O Dia de Finados fora mantido não por ser costume religioso católico, mas por seu caráter popular/cultural de reverência aos mortos, já arraigado no sentimento da população, que como foi visto não entrava em choque com o positivismo, que também era um culto aos mortos. A despeito dos protestos, o calendário foi, em tese, mantido; na prática, em março, o governo dispensou do ponto os empregados públicos, em alguns dias da Semana Santa.

Em 1891, uma nova data é acrescida ao calendário oficial: o dia 24 de fevereiro é decretado como festa nacional para comemorar a promulgação da Constituição da República. $^{9}$ 
Somente em 1892 é que surgem as primeiras tentativas de reforma do calendário decretado. Os positivistas da IPB saíram em sua defesa por conta de um projeto de lei apresentado no Senado por Ubaldino do Amaral e Campos Sales, que, invocando o aumento dos dias de trabalho, propunha reduzir o número dos feriados do calendário oficial. A proposta votada no Senado mantinha os feriados da promulgação da Constituição Federal, da abolição da escravidão, da independência e da proclamação da República, somente as datas ligadas estritamente à história brasileira, excluindo inclusive a festa do descobrimento. As datas que ligavam o Brasil à história ocidental, promovendo a fraternidade entre os povos, segundo os positivistas, foram suprimidas na proposta ao Senado, justamente aquelas que davam o teor mais positivista ao calendário, embora o argumento para a redução fosse econômico. Vários grupos protestaram, inclusive membros do Senado, mas a votação foi ganha por maioria. Entretanto, em função do protesto, os membros da Câmara dos Deputados rejeitaram o projeto quase por unanimidade. ${ }^{10}$

Por conta da necessidade de uma educação cívica da população ou para poder explicar o significado das datas, alguns autores publicaram livros sobre o calendário. $\mathrm{O}$ primeiro deles é de Rodrigo Otávio, Festas Nacionais, em 1893, com uma carta/introdução de Raul Pompéia. Em 1921, Coelho Netto publicou Breviário Cívico, tentando explicar cada uma das datas do calendário segundo uma lógica cristã. A confusão das datas e a incompreensão do calendário oficial republicano também eram exploradas nas revistas humorísticas ilustradas, como mostra Velloso (2000, p.129-51).

O calendário se manteve inalterado até 1922, quando o governo declarou feriado nacional o dia 25 de dezembro. O $1^{\circ}$ de maio foi acrescentado em 1924. Com essas alterações, sobretudo pela inclusão de um feriado religioso em um calendário oficial, o positivista Reis Carvalho publicou Os Feriados Brasileiros, em 1926, exigindo, em vão, a separação entre Igreja e Estado, princípio defendido pelo grupo desde o fim da monarquia. Em 1930, Getúlio Vargas decretou ampla reforma no calendário.

\section{A participação da IPB em celebrações públicas e o uso de obras de arte}

Durante a monarquia, os membros da IPB não participavam das festas oficiais. As celebrações em que estavam presentes eram aquelas organizadas pelo próprio grupo, voltadas para cultuar alguma celebridade histórica, brasileira ou não. $\mathrm{O}$ 
desenvolvimento do culto, que como foi visto integrava atividades religiosas familiares, no Templo e atividades cívicas, era o objetivo basilar da estratégia de ação estabelecida pelo Diretor Miguel Lemos, seguido de organização do ensino e de intervenção nos negócios públicos (Lemos, 1981, p.21).

As celebrações cultuais eram vistas como o principal veículo de divulgação do positivismo, no início dos 1880. Quando Miguel Lemos fez um acordo com o redatorchefe da Gazeta de Notícias para criar uma coluna no jornal, chamada Centro Positivista, uma série de três artigos de Teixeira Mendes, que inaugurou a coluna, tratou de uma tentativa de reforma do calendário, mais precisamente da eliminação dos anos bissextos, proposta de Castro Lopes. A proposta foi criticada pelos positivistas, que entendiam que os anos bissextos não deveriam ser suprimidos (Mendes, 1881).

Miguel Lemos, no Relatório de 1881, explicita críticas às festas do regime monárquico, dizendo que haviam perdido a animação, que não mais comoviam o povo, que eram "a morte do entusiasmo público" (Lemos, 1981, p.32). Para ele, a principal causa era o descrédito na Monarquia - vista como um regime transitório à República - e descrença no regime constitucional. A religião do civismo, tal como estava sendo instituída pelos positivistas, visava, no seu entender, despertar o povo da atonia e fazia parte da campanha política contra a Monarquia. É difícil precisar o significado da palavra povo para os positivistas, já que estes desenvolveram atividades voltadas para um público escolarizado, deixando à margem grande parte da população analfabeta que compunha o "povo". Inclusive as festas cívicas promovidas por estes, que a princípio poderiam congregar o "povo", eram de caráter bem intelectualizado, ocorrendo conferências e discursos.

Os festejos do tricentenário da morte de Camões, que ocorreram simultaneamente no Rio de Janeiro e em Paris, em 10 de junho de 1880, inauguraram as atividades de culto cívico do grupo. No Brasil, a festa aconteceu no Teatro Ginásio, que foi decorado com bandeiras por Aníbal Falcão. Primeiro, ocorreu uma sessão pública com a apreciação histórica da vida de Camões e sobre Portugal, por Teixeira Mendes; e, depois, a execução do Hino à Humanidade, adaptado da Marselhesa por Teixeira de Souza. O evento em homenagem ao português tinha por objetivo reconciliar os brasileiros com a "mãe-pátria" e desenvolver o sentimento de continuidade histórica (ibidem, p.15). A solenidade prosseguiu com uma passeata noturna, aberta com o busto de Camões e outras insígnias religiosas positivistas. O busto, feito pelo escultor Candido Caetano de Almeida Reis, levado em procissão, foi exposto provisoriamente na 
Biblioteca Nacional, no Rio de Janeiro, até que fosse construído um Templo à Humanidade. ${ }^{11}$ Encerrando os festejos, eles prepararam uma edição "elegante" de poesias líricas seletas de Camões.

Em setembro do mesmo ano, a Sociedade celebrou ainda a morte de Comte, com um discurso público, no Salão Mozart, de Teixeira Mendes, e uma procissão até o túmulo de Oliveira Guimarães, o iniciador do movimento positivista organizado no Brasil. À colocação de uma coroa de flores seguiu um discurso de Benjamin Constant.

Desde 1881 que o 7 de setembro era proposto pelos positivistas para ser o dia da Festa Nacional. A Circular do Centro Positivista Brasileiro, assinada pelo diretor Miguel Lemos, foi publicada em vários jornais cariocas e chamava os fluminenses a se integrarem nos festejos e instituírem a religião do civismo, justificando que o culto pátrio era necessário para o engrandecimento nacional e que todas as outras nacionalidades tinham as suas datas. ${ }^{12}$ Conclamava ao final: "mostremos ao mundo que temos uma Pátria e que sabemos saudá-la..." 13 O positivismo, com pouco alcance popular e sem se aliar ao governo monárquico, não conseguiu fazer uma grande festa. $\mathrm{O}$ relato diz que Miguel Lemos fez um discurso comemorativo no Congresso Ginástico Português. Nesta época, as comemorações oficiais eram poucas, e as festas de 7 de setembro eram realizadas em eventos particulares, como vinham propondo os positivistas.

Em 1881, o grupo comemorou o 14 de julho, sendo Danton o homenageado. Para esta comemoração, após a conferência pública, os positivistas inauguraram na sala do Centro Positivista o retrato de Dr. Robinet, historiador positivista dedicado a estudar a biografia de Danton. Somente no ano de 1884, eles homenagearam ToussaintLouverture, na festa comemorativa da Revolução Francesa. No evento, também inauguraram seu retrato, pintado por Aurélio de Figueiredo.

O centenário do Marquês de Pombal também foi comemorado pelo grupo, em 8 de maio de 1882, com uma conferência pública. No dia seguinte, ocorreu uma procissão cívica, organizada pelo Clube de Regatas e alunos das escolas. Conforme relato de Miguel Lemos, a marcha foi composta por alunos da Marinha, da Escola de Medicina, da Escola Politécnica, alunos das escolas secundárias e do Liceu de Artes e Ofícios. A Sociedade Positivista foi especialmente convidada para o cortejo, disse Miguel Lemos. Quatro membros da sociedade ajudaram quatro alunos a levar o andor com o busto do Marquês. À frente do grupo, marchavam outros positivistas, precedidos da bandeira 
verde da IPB, com o slogan Ordem e Progresso. Após a festa, o busto foi doado aos positivistas (Lemos, 1908, p.17-8).

A partir de 1884, Tiradentes foi incorporado no que os positivistas chamavam de festas sociolátricas, mas sempre em eventos próprios. Milliet, em sua tese, refere-se às festas a Tiradentes realizadas no período monárquico, sob iniciativa do Clube Tiradentes, e ressalta que os positivistas se incorporaram à festa coletiva somente após a República. De fato, nos relatórios da IPB desse período, não há referências de que tenham se unido ao Clube Tiradentes nos eventos por ele organizados (Milliet, 1998, p.80-2).

Os eventos preparados pelos positivistas normalmente eram conferências públicas, com salão decorado com a imagem e a temática histórica relacionada ao homenageado; eram abertos ao público e tinham pouca repercussão nos jornais. Eles usavam as expressões festa, celebração ou culto cívico para designar o mesmo evento. Os relatos que existem são os dos próprios positivistas, nos folhetos e relatórios anuais. No relatório de 1881, Miguel Lemos esclarece que estas celebrações eram mais ensino do que culto, pois assim era necessário àquela platéia de brasileiros, naquele momento. Um dos relatos desses eventos revela que havia cerca de 500 pessoas ouvindo a conferência. Os freqüentadores eram militares, professores, funcionários públicos, mulheres e estudantes, não necessariamente adeptos do positivismo. Certamente alguns curiosos freqüentavam as conferências, pois neste momento o positivismo não era ainda muito conhecido do público brasileiro, tampouco havia se tornado alvo dos ataques de intelectuais e políticos, descontentes com a ortodoxia doutrinária de Miguel Lemos e Teixeira Mendes, o que passou a ocorrer durante o Governo Provisório da República.

Percebe-se nos jornais cariocas que outros grupos também faziam chamadas para a realização de celebrações cívicas, em 14 de julho, por exemplo, mas os positivistas não participavam. Nos anos de 1881, 1882 e 1883, a comunidade francesa no Rio de Janeiro se reuniu para celebrar a data. Neste último ano, uma chamada no Jornal do Commércio conclamava os abolicionistas a se juntarem à festa, fazendo uma associação entre o anseio de abolição da escravidão no Brasil e o lema francês Liberdade, Fraternidade e Igualdade. ${ }^{14}$ Embora os positivistas fossem abolicionistas, não há referência de que tenham aceitado o convite para a celebração.

Com a República e a decretação do calendário de festas nacionais, os positivistas da IPB passaram a participar delas, em comitiva, unindo-se a outros grupos. Esta atuação durou pouco, apenas até 1892. Três fatores parecem ter colaborado para o 
isolamento dos positivistas das celebrações coletivas: primeiro, a promulgação da Constituição os deixou parcialmente contemplados, mas inconformados quando o governo não a cumpria; segundo, o apoio de alguns militares, não adeptos, mas seguidores da IPB, ao governo de Floriano Peixoto; o terceiro motivo foi a celebração frustrada de um ano de morte de Benjamin Constant, em 1892, planejada para ocorrer no Cemitério da Santa Casa de Misericórdia. A celebração foi projetada pelos positivistas da IPB e por militares ex-alunos do homenageado e lhes evidenciou que a separação entre Igreja e Estado não estava sendo cumprida pelo governo.

O ano de 1890 foi promissor no que se referia às festas. No relatório da IPB deste ano, aparece a verba destinada para festas públicas, discriminando três delas: festa de Tiradentes, 70\$000; festa de 3 de maio, 11\$800; e festa de 15 de novembro, $20 \$ 000$. Se somarmos os 60\$000 do estandarte feito para ser inaugurado na festa a Tiradentes, tem-se o total de 161\$800 gasto nas festas cívicas, quase o equivalente às despesas de compra da IPB em livros ou móveis, naquele ano (Lemos, 1892, p.46-7).

A primeira festa republicana do calendário foi a de Tiradentes, em 1890, organizada pelo Clube Tiradentes. ${ }^{15}$ Em abril, todos estavam ainda contagiados pelo entusiasmo com a República, até mesmo os positivistas da IPB, que participaram ativamente da festa junto com clubes abolicionistas e republicanos, estudantes, militares e operários. Na versão da Igreja, os positivistas tomaram parte saliente da procissão cívica, levando o andor com o busto de Tiradentes, feito por Almeida Reis. O Estandarte da Humanidade, pintado pelo artista Décio Villares, teve sua inauguração pública nesta festa. $\mathrm{O}$ artista ainda distribuiu aos presentes uma litografia com a imagem de Tiradentes, encomendada pela Igreja (Lemos, 1892, p.9-10).

Nos textos da IPB, não há referência às demais festas do calendário, apenas à destinação de $20 \$ 000$ da despesa de 1890 para a festa de 15 de novembro; no entanto, não há descrição desta. Segundo Siqueira, o governo federal promoveu e dirigiu a festa de 15 de novembro de 1890, destacou sobretudo a presença militar, que aparecia como a instituição salvadora e tinha Deodoro da Fonseca como figura central nos festejos. A autora reconhece que as disputas políticas se davam também entre os republicanos, mas destaca que na festa de 1890 a motivação do governo era demonstrar força diante da oposição monarquista (Siqueira, 1995, p.50). É possível apenas supor que os positivistas não participaram dessa festa pelo caráter oficial de que ela se revestiu e também porque não aceitavam a liderança de Deodoro, pois achavam que este nunca deixou de ser 
monarquista, além de sua autopromoção a Generalíssimo, o que deixou os positivistas muito descontentes.

A festa de 14 de julho e a de 7 de setembro tiveram a distribuição das litografias de Danton e José Bonifácio, criações de Décio Villares, mas não há registro de que tenham sido atividades fora do círculo de positivistas da IPB.

\section{Arte, artistas e positivismo}

É necessário compreender a relação dos artistas colaboradores da IPB com o positivismo. Candido Caetano de Almeida Reis foi um dos primeiros artistas a realizar obras de arte para a Igreja (dois bustos e uma estatueta), que o considerava um positivista "incompleto": morreu em 1889, sem declarar sua adesão à doutrina. A IPB considerava-o o primeiro artista a ser influenciado pelo positivismo e mandou construir seu túmulo (Mendes, 1925). O artista Aurélio de Figueiredo "flertava" com o positivismo, mas também nunca declarou publicamente essa tendência. Ele e Décio Villares apresentaram, em 30 de janeiro de 1890, ao Ministro dos Negócios do Interior, uma proposta de ensino artístico e de extinção da Academia de Belas Artes. O projeto era baseado na concepção comteana de estética e de ensino. Não há muitos dados na documentação da IPB acerca desse artista. Três quadros seus integram o acervo da mesma. Dos três artistas citados, Décio Villares era o único que assumira sua adesão à Religião da Humanidade, desejando inclusive se casar na IPB. Entre 1895 e 1905, recebeu uma pensão da Igreja, tendo como atribuições executar obras de arte para o acervo, dar aulas de desenho aos filhos dos membros positivistas e coordenar os trabalhos artísticos e de decoração nas celebrações cívicas. ${ }^{16}$

Para o positivismo, a obra de arte tem seu valor estético atrelado à elevação moral do artista. Não era qualquer artista que poderia executar uma obra que seria utilizada no culto público. Os dois primeiros artistas, embora não tivessem explicitado sua adesão à estética positivista, colaboraram com a IPB doando obras de arte para ornar a sala de reuniões, na Rua do Ouvidor, na década de 1880. Se não aderiram explicitamente ao positivismo, nem o rechaçaram, colaboraram com ele. A Igreja, ao aceitar as doações de obras, ao que parece, aceitava ou reconhecia a elevação moral desses artistas, mesmo não positivistas.

O quadro a seguir revela algumas contribuições destes três artistas às festas cívicas que a IPB realizou ou de que participou. Não estão arroladas todas as obras dos 
artistas pertencentes ao acervo da Igreja, apenas aquelas que foram confeccionadas visando a alguma comemoração cívica, entre 1880 e 1890, período de abordagem deste texto. O quadro foi elaborado a partir do inventário de obras de arte do acervo da IPB e de suas publicações.

I - Obras de arte do acervo da IPB e comemorações cívicas

\begin{tabular}{|c|c|c|c|}
\hline Objeto & Artista & Ano & Festa \\
\hline Busto, Camões & $\begin{array}{l}\text { Candido Caetano } \\
\text { de Almeida Reis }\end{array}$ & 1880 & Festa do tricentenário de Camões \\
\hline Retrato, Dr. Robinet & ? & 1881 & $\begin{array}{l}\text { Festa do aniversário da Revolução } \\
\text { Francesa }\end{array}$ \\
\hline Busto, Marquês de Pombal & ? & 1882 & $\begin{array}{l}\text { Festa do centenário do Marquês de } \\
\text { Pombal }\end{array}$ \\
\hline Retrato, Toussaint-Louverture & \begin{tabular}{|l|} 
Aurélio \\
Figueiredo \\
\end{tabular} & 1884 & $\begin{array}{l}\text { Festa do aniversário da Revolução } \\
\text { Francesa }\end{array}$ \\
\hline Retrato, Danton, reprodução & $?$ & 1887 & $\begin{array}{l}\text { Festa do aniversário da Revolução } \\
\text { Francesa }\end{array}$ \\
\hline Busto, Tiradentes & $\begin{array}{l}\text { Candido Caetano } \\
\text { de Almeida Reis }\end{array}$ & 1890 & Festa cívica a Tiradentes \\
\hline Busto, Cristóvão Colombo & Décio Villares & 1890 & Festa cívica da Descoberta do Brasil \\
\hline Estandarte da Humanidade & Décio Villares & 1890 & Festa cívica a Tiradentes \\
\hline Litografia, Danton & Décio Villares & 1890 & $\begin{array}{l}\text { Festa do aniversário da Revolução } \\
\text { Francesa }\end{array}$ \\
\hline Litografia, José Bonifácio & Décio Villares & 1890 & Festa da Independência do Brasil \\
\hline Litografia, Tiradentes & Décio Villares & 1890 & Festa cívica a Tiradentes \\
\hline $\begin{array}{l}\text { Quadro, A } 1^{\text {a }} \text {. Missa no Brasil, } \\
\text { de Victor Meirelles, reprodução }\end{array}$ & Décio Villares & 1890 & Festa cívica da Descoberta do Brasil \\
\hline $\begin{array}{l}\begin{array}{l}\text { Medalhão, Infante } \\
\text { Henrique }\end{array} \\
\text { Dom } \\
\end{array}$ & Décio Villares & 1890 & Festa cívica da Descoberta do Brasil \\
\hline Medalhão, Marco Pólo & Décio Villares & 1890 & Festa cívica da Descoberta do Brasil \\
\hline $\begin{array}{l}\text { Medalhão, de Américo } \\
\text { Vespúcio }\end{array}$ & Décio Villares & 1890 & Festa cívica da Descoberta do Brasil \\
\hline Medalhão, Hiparco & Décio Villares & 1890 & Festa cívica da Descoberta do Brasil \\
\hline Retrato, Vasco da Gama & Décio Villares & 1890 & Festa cívica da Descoberta do Brasil \\
\hline Retrato, Pedro Álvares Cabral & Décio Villares & 1890 & Festa cívica da Descoberta do Brasil \\
\hline $\begin{array}{lll}\text { Retrato, } & \text { Affonso } & \mathrm{de} \\
\text { Albuquerque } & & \\
\end{array}$ & Décio Villares & 1890 & Festa cívica da Descoberta do Brasil \\
\hline Retrato, Fernão de Magalhães & Décio Villares & 1890 & Festa cívica da Descoberta do Brasil \\
\hline
\end{tabular}

É interessante observar que, dos grupos envolvidos na promoção de festas cívicas, como o Clube Tiradentes, Clube Republicano Lopes Trovão, Clube Militar, Igreja Positivista, Clube Republicano da Faculdade de Medicina, Escola Militar, Batalhões Acadêmicos, Escola Politécnica e outros, somente a IPB possuía um acervo de obras de arte, bustos principalmente, que poderia ser utilizado nos eventos. Há apenas dois registros de bustos de Tiradentes pertencentes ao Clube Republicano Lopes Trovão e ao Clube Tiradentes, que eram utilizados nas festas de 21 de abril, desde 1881. 
Mesmo o Clube Militar, hoje com um acervo artístico bastante variado, não empregava suas obras nas celebrações.

O investimento da IPB na constituição de um acervo artístico, grande parte formado por bustos, deu-se por razões doutrinárias. Como foi visto, a implementação do culto cívico era meta básica a ser desenvolvida. O culto eficiente, aquele que tocaria no sentimento da população, que desenvolveria suas emoções cívicas e que a educaria para uma sociabilidade civil, necessitava ter por apoio a contemplação de imagens dos heróis. A arte positivista tinha um sentido pragmático e não de pura contemplação estética. A arte, como uma das formas de operacionalização da memória e da emoção, era vital para o culto cívico positivista. A festa de 3 de maio é um evento exemplar neste sentido.

\section{A arte e a festa de 3 de maio de 1890}

Em nenhuma outra festa, nem no centenário de morte de Tiradentes em 1891, em que ocorreu um evento grandioso, o emprego de obras de arte e objetos em geral foi tão planejado como na festa de 3 de maio de 1890.

Segundo os jornais, a festa esteve a cargo de uma comissão de oficiais do exército e da armada, formada por Carlos Accioli, Antonio Maximino Gomes Ferras, Augusto Tasso Fragoso, Annibal Eloy Cardozo, Saturnino Nicolao Cardozo, Nelson de Vasconcellos e Almeida, Nepomuceno Baptista, João Augusto de Amorim Rangel, João Gualberto de Mattos, Thomas Cavalcante de Albuquerque. Segundo Miguel Lemos, a festa teve a coordenação artística de Décio Villares e foi organizada segundo as indicações da IPB. Os jornais não confirmam esta informação de Miguel Lemos, porém raramente os relatos das festas entram nos pormenores de sua preparação. Fica-se entre a informação parcial dos jornais e o relato, muitas vezes superdimensionado, dos positivistas. Apenas o Jornal do Commércio confirma que todas as obras de arte empregadas no cortejo cívico eram de Décio Villares. ${ }^{17}$

É possível crer que a comissão encarregada trabalhou em conjunto com Miguel Lemos e Teixeira Mendes, pois se tem informação de que os cinco primeiros componentes conheciam e se correspondiam com os diretores da IPB e alguns inclusive colaboravam financeiramente com ela. Alguns deles, ex-alunos de Benjamin Constant na Escola Militar, diziam-se positivistas. ${ }^{18}$ É interessante como alguns militares estiveram envolvidos em iniciativas de celebrações cívicas e confecção de obras de arte 
e imagens em geral, fruto de uma leitura do positivismo, reforçada pelos hábitos ritualísticos do exército e por uma aguda sensibilização cívica no início da República. $\mathrm{Na}$ correspondência de Miguel Lemos e Teixeira Mendes, encontram-se cartas de alguns jovens militares pedindo orientação para os mais diversos assuntos, e notícias de suas iniciativas concernentes às comemorações. A orientação "espiritual" dos mestres positivistas também se estendia a assuntos pessoais, como casamento, carreira militar e vida política. Não é difícil supor que a IPB tenha assumido a organização dos preparativos para a festa cívica da descoberta do Brasil, tendo o apoio de um artista e chancela dessa comissão promotora.

No relatório anual da IPB de 1890, o diretor narra que o homenageado daquela festa das comemorações da descoberta foi Colombo. O busto, feito por Décio Villares, foi carregado em um andor, enfeitado também com imagens de nautas, astrônomos e viajantes, além da rainha espanhola - Isabel -, protetora do navegante italiano. Todos estes, explica, foram os que mais "concorrêrão para preparar e completar esse grande movimento marítimo prezidido por Colombo, e do qual a descobérta do Brazil é apenas um epizódio" (Lemos, 1892, p.10).

Os jornais descrevem melhor o andor da IPB e outros andores e imagens. A narrativa mais detalhada da procissão e das imagens utilizadas é da Gazeta de Notícias. Este jornal, como visto, tinha estreita relação com a IPB desde sua fundação em 1881, quando foi criada a coluna Centro Positivista. O relato descreve com minúcia todos os objetos e imagens e explica seus significados na homenagem à descoberta do Brasil. Tal pormenorização descritiva não parece ter sido fruto apenas da observação do repórter naquele dia; é possível que os membros da IPB tenham sido consultados para explicar o conjunto de cenas montadas para a procissão cívica ou que tenham fornecido ao jornal um texto explicativo sobre a organização desta. Os outros periódicos não apresentaram tal nível de detalhamento.

A procissão pode ser dividida em três blocos temáticos, cada um deles composto por andor com imagens. Os três blocos formam cenas em movimento, no qual participantes e objetos são agentes construtores de novas imagens. Como descreve Miguel Lemos sobre uma outra festa, mas que bem serve para esta: “A música, as luzes, as bandeiras de vivas cores, os vivas entusiásticos da multidão completam este admirável quadro" (Lemos, 1908, p.18). 
O primeiro bloco foi aberto pelo Ministro da Marinha e seu Estado-Maior. Seguia sua comitiva o primeiro andor da parada cívica, composto por uma réplica da caravela usada por Cabral, quando do descobrimento do Brasil. O andor era carregado por um grupo de marinheiros. Seguindo estes, outros marinheiros, os do encouraçado Aquibadan carregavam seus cabos e remos. Completando esse bloco, os marinheiros do encouraçado Riachuelo levavam um andor com outra caravela igual à de Cabral, com dois metros de comprimento. A caravela foi colocada sobre uma coluna octogonal, para ficar mais alta e visível. Em quatro faces desta coluna foram pintados retratos de Vasco da Gama, Pedro Álvares Cabral, Affonso de Albuquerque e Fernão de Magalhães; nas outras faces foram escritos os nomes de outros navegadores: Cook, Tasman, Cabot e Solis. Neste andor ainda tremulava uma bandeira portuguesa e uma flâmula da marinha de guerra portuguesa.

O bloco central era o da Igreja Positivista, cujo homenageado era Colombo. Abria o bloco o Estandarte da Humanidade, descrito em pormenores apenas na Gazeta de Notícias. Um outro estandarte ou bandeira vinha atrás. Este reproduzia um "escudo luso-brasileiro": a parte superior tinha as cores azul e branco, a parte inferior amarelo e verde; ao centro, unindo as cores representativas de Portugal e Brasil, havia uma grande cruz de cor vermelha, simbolizando o primeiro nome do Brasil; nesta cruz, estava reproduzido o quadro de Victor Meirelles, a Primeira Missa no Brasil. O andor com o busto de Colombo encerrava a participação do grupo positivista. $\mathrm{O}$ busto fora colocado sobre uma coluna rostral, ${ }^{19}$ cuja base tinha medalhões com retratos do infante Dom Henrique, de Marco Pólo, de Américo Vespúcio e de Hiparco; entre estes estavam escritos os nomes de Pitéias, Ptolomeu, Neper e Lacaille. Colombo fora idealizado no busto com uma vestimenta que permitia visualizar um medalhão com a imagem de Isabel - a católica.

O terceiro bloco era formado pelo andor representando a civilização indígena. Os marinheiros do cruzador Guanabara levavam o andor com uma almadia ou piroga ${ }^{20}$ indígena, com um troféu de armas e o retrato de um indígena, "representando a civilização marítima dos selvagens da época". ${ }^{21}$ Para a Gazeta da Tarde a embarcação era uma jangada. ${ }^{22}$ Explica a Gazeta de Notícias que este andor e o primeiro (o da réplica da embarcação de Cabral) representam o encontro das duas civilizações marítimas da época, a européia e a indígena americana.

Os outros grupos também integravam a procissão, porém sem andores, apenas portando suas vestimentas, bandeiras e estandartes distintivos. Cerca de 25 sócios do 
Clube Militar se fizeram representar na festividade, a cavalo. A guarda de honra do Batalhão Acadêmico compareceu com o mesmo fardamento que usara por ocasião da revolta do segundo regimento, quando esteve aquartelada no episódio da Proclamação da República. ${ }^{23}$ De carro, chamou a atenção a presença do Liceu Literário Português com seu estandarte, seguido de um carro com um grupo de meninas vestidas de branco, com fitas a tiracolo, nas cores nacionais. ${ }^{24}$

A composição dos andores, reunindo diferentes objetos e imagens e referências a diversos personagens históricos, assemelha-se à construção de uma cena em um quadro ou em um monumento positivista. Neste tipo de arte, assim como no andor, o homenageado nunca estava solitário; ele era cercado por aqueles que contribuíram para a consecução do fato histórico. Isso era o que os positivistas chamavam de síntese perfeita: uma composição estética em que tudo se resumia em um único pensamento; uma composição que tivesse vários elementos, mas que formasse uma só idéia. A síntese permitia ao espectador chegar à compreensão narrativa, e esta levava à reação emotiva, ao sentimento cultual e ao entusiasmo cívico. Pode-se pensar que houve a busca da síntese nos andores individualmente e no conjunto dos três blocos. O grande número de personagens em uma composição artística era uma das formas de distinção dos artistas positivistas e também o maior alvo de críticas e ridicularizações. Se de fato os positivistas definiram a temática e a ordem dos andores, isso nos permite algumas interpretações.

A primeira é o próprio significado da festa de 3 de maio, a festa do descobrimento do Brasil. Em alguns jornais, esta data é expressa como a festa do nascimento da pátria; é o dia em que o Brasil passou a figurar no quadro das nações civilizadas; "é o dia do primeiro impulso na existência das nações". ${ }^{25}$ A primeira comemoração do calendário republicano em 1890 foi a um personagem - Tiradentes; o 3 de maio estava comemorando a própria pátria; era a primeira comemoração republicana ao nascimento da pátria brasileira. O editorial de 3 de maio da Revista Ilustrada apresenta uma analogia entre República e nascimento, intitulada: "Dobramos o cabo". ${ }^{26}$ Fazendo uma retrospectiva da queda da monarquia, que no editorial significava dobrar o cabo, uma alusão à conquista da rota para as Índias por Vasco da Gama, continuada por Cabral, a revista relacionava o advento da República à descoberta do Brasil. 
Ferreira Neto apresenta outra interpretação possível a respeito do significado desta festa do descobrimento. Ela assinalava a descendência nacional do Brasil e estabelecia hierarquias inquestionáveis, porque marcadas pelo sangue, "identificando claramente os supostos pais da nacionalidade e seus herdeiros" (Ferreira Neto, 1989, p.77). Para ele, das festas de 1890, a de 3 de maio foi talvez a mais simbólica porque versava sobre um período oculto, longínquo e incognoscível da História - o Brasil em 1500 estava em virtual estado puro, era uma nação em gestação, momento de "ruptura criadora primordial, momento de transcendência da própria história" (ibidem). A festa também era hermética porque somente um grupo seleto poderia entender esse discurso das origens. Somente alguns letrados, superado o desconhecimento histórico, conseguiam compreender o significado das figuras e das inscrições que foram mostradas nos andores. A apenas uma seita de iniciados era dado o direito de entendimento sobre o nacional; com isso, preservou-se o mistério da criação, concluiu o autor.

Como explicar a homenagem a Colombo e não a Cabral? Parece que havia um problema estratégico: homenagear a descoberta do Brasil e evitar que isso fosse transformado em uma apologia aos portugueses e aproveitado pela oposição monarquista. A solução foi homenagear Colombo - italiano -, e não Cabral português. $\mathrm{O}$ andor mais tematicamente português, o que apresentava a réplica da caravela de Cabral, a bandeira e os navegantes portugueses, era contrabalançado pelos nomes de navegantes de outros reinos, e Cabral, o potencial homenageado, ficava em meio a todos esses personagens. A imagem central do andor era a caravela, e Cabral não foi honrado com um busto. Explicava Miguel Lemos que a descoberta do Brasil foi apenas um episódio no movimento marítimo; por conseqüência, Cabral foi apenas um navegante dentre tantos outros. É possível também que os positivistas estivessem antecipando a onda de celebrações em torno da figura de Colombo, realizadas em várias partes do mundo, sobretudo na América, a partir de 1892.

Era natural que as homenagens convergissem para Cabral. Os jornais demonstraram essa expectativa. O jornal $O \mathrm{Paiz}$, por exemplo, tinha como perspectiva que no evento daquele dia figurariam as insígnias e emblemas alusivos ao descobrimento do Brasil, pelo navegante Cabral. ${ }^{27}$ O Diário de Notícias apresentou uma coluna dedicada à colônia portuguesa, lembrando aos brasileiros que Portugal era o berço da vida, o berço do Brasil, e que isso se devia a Cabral. Mesmo após a marcha cívica, o periódico continuava insistindo que o evento fora em homenagem ao 
navegante português. Para o diário, fazendo uma lógica atribuição, o busto carregado pelos positivistas era o de Augusto Comte, não o de Colombo. ${ }^{28}$ Talvez aqui se possa pensar na hipótese de que a festa era compreensível apenas a alguns mais intelectualizados, como defendeu Ferreira Neto. A confusão dos bustos e a insistência dos jornais em que o homenageado era Cabral demonstra que as imagens desses personagens eram pouco conhecidas. A educação cívica que tais festas ensejavam requeria uma educação visual.

Outro ponto que vale discutir é o tema do encontro entre as civilizações européia e americana, representado pelos andores da caravela e da piroga indígena. Os positivistas tinham consciência de que este encontro havia sido responsável pela dizimação indígena e pela apropriação de suas terras, tema de alguns de seus folhetos ainda nesta década e de sua rejeitada proposta de Constituição republicana, no ano seguinte. Para eles, isso poderia ser revertido ou minimizado se a Constituição republicana garantisse autonomia "às hordas fetichistas - enquanto estados livremente confederados à República brasileira". ${ }^{29}$ Propunham que a República fosse formada pela livre federação dos povos, composta por dois estados confederados autônomos: os Estados Ocidentais Brasileiros, formados pela fusão do europeu, com o africano e o americano aborígine; e Estados Americanos Brasileiros, constituídos pelas "hordas fetichistas" esparsas pelo território brasileiro (Lemos \& Mendes, 1934, p.1). Assim a composição étnica e territorial brasileira ficaria dividida em uma população mista, fruto da fusão das três raças, e uma população pura, autóctone americana, que deveria receber proteção governamental. O estágio civilizatório dos índios ainda não miscigenados deveria ser respeitado, e sua integração aos ocidentais feita de forma gradual, o que não havia ocorrido na época do descobrimento.

Os periódicos apresentavam visão diferente dos positivistas quando se referiam ao encontro desses povos. Além da chegada da civilização, trazida pelos portugueses, como já foi referido, havia também uma analogia entre trevas e luz, reforçando o argumento de que os indígenas selvagens deveriam ser abatidos para dar lugar à ciência e ao progresso trazidos pelos europeus. ${ }^{30}$ A Revista Ilustrada apresentou essa idéia em duas imagens colocadas lado a lado, aludindo ao 3 de maio de 1500 e ao de 1890 . A primeira reproduz a chegada dos portugueses à costa brasileira, estes observados pelos índios curiosos e escondidos na mata densa. A segunda imagem apresenta a festa do descobrimento, cujas figuras de destaque são a caravela, o busto de Colombo, a 
população, a iluminação em arco na Rua do Ouvidor e as inúmeras bandeiras que decoravam as sacadas dos prédios. No Brasil civilizado, não havia mais índios, havia cidadãos e luz elétrica, uma das maiores insígnias de progresso para a época. A seguir são reproduzidas tais imagens. ${ }^{31}$

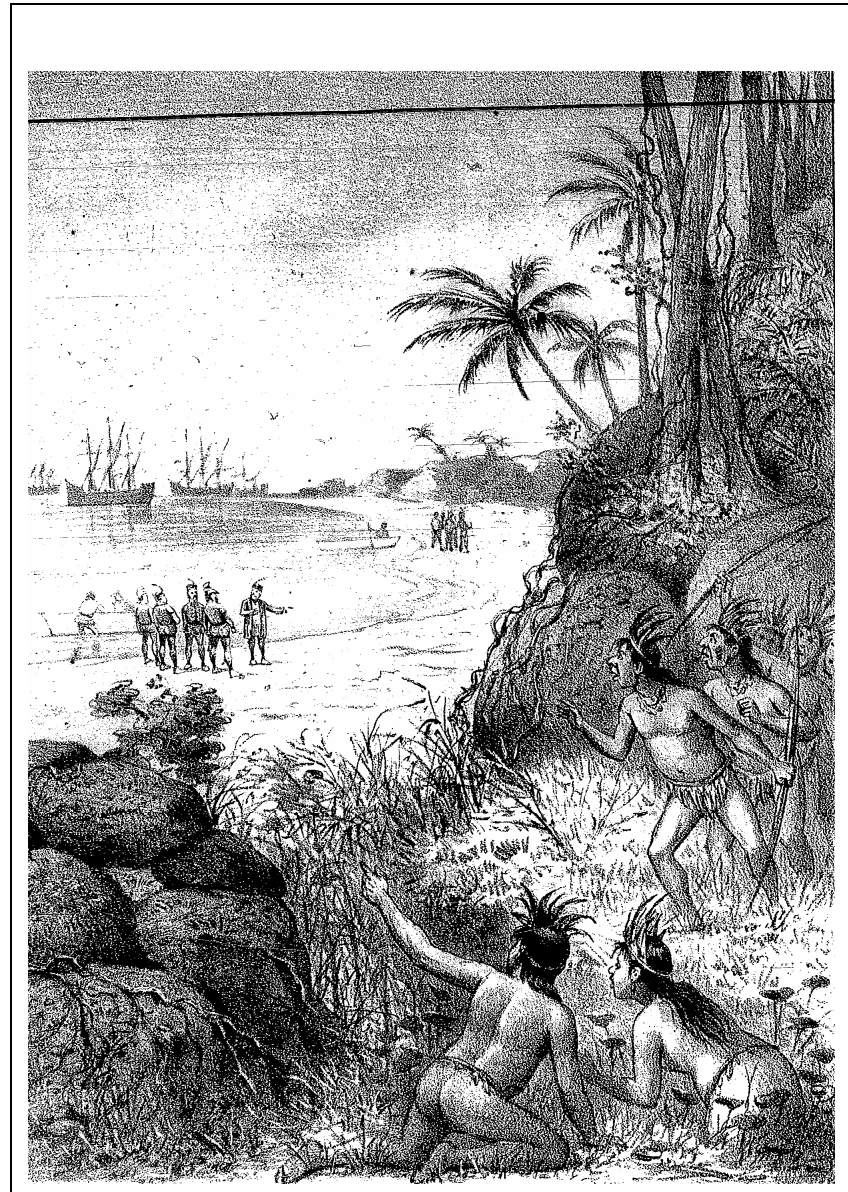

FIGURA 1 - 03 de Maio de 1500

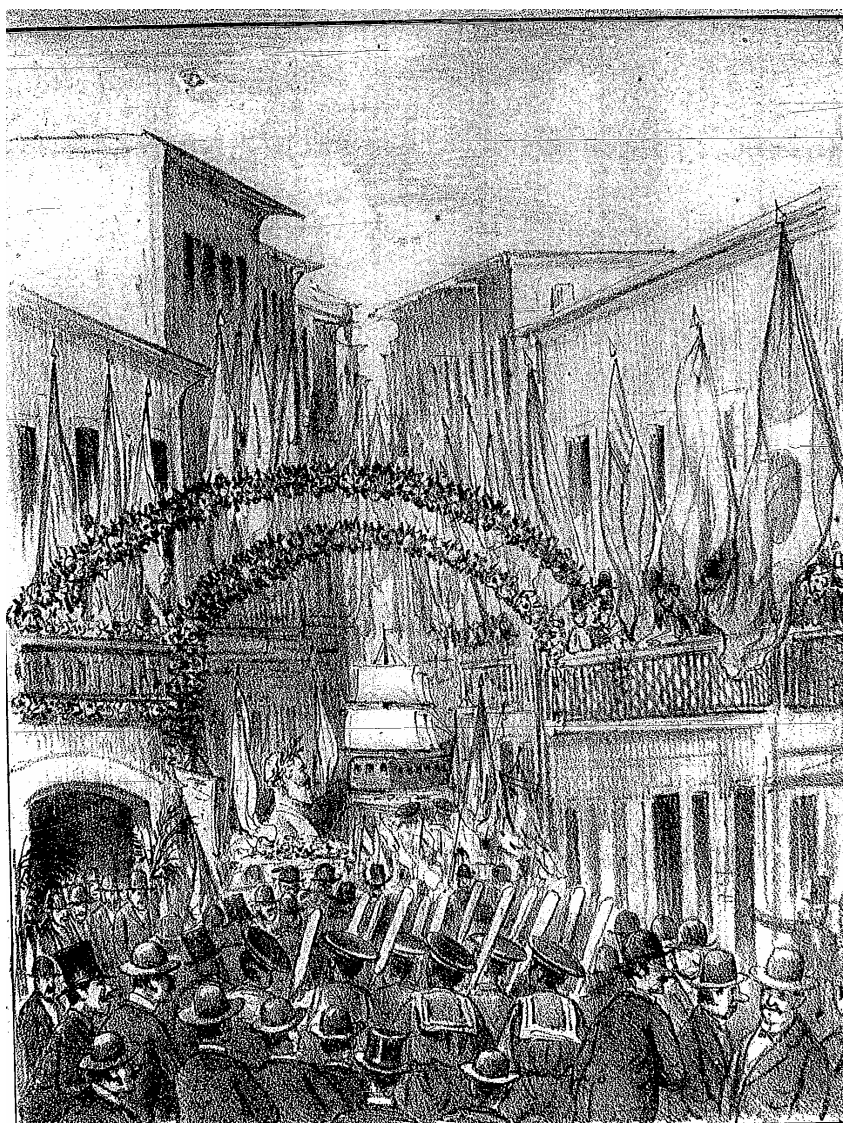

FIGURA 2 - 03 de Maio de 1890

Ferreira Neto propõe outra analogia bem pertinente ao analisar o significado dos andores. "O encontro de brancos e indígenas era uma clara alegoria da nova sociedade republicana, na imaginação de seus crentes letrados e na prática de seus rituais." (Ferreira Neto, 1989, p.79). Os letrados republicanos assumiam o poder e o papel dos europeus civilizados, e o povo, analfabeto ignorante dos mistérios da História do Brasil, ficava com o papel de indígenas.

Um terceiro ponto que se destaca para análise é a ordem dos blocos e a posição dos positivistas. Para quem assistia à procissão cívica, a ordem construída era de uma lógica histórica. Os navegantes portugueses, no primeiro andor, representados simbolicamente pela caravela, tiveram a intermediação da Igreja, no segundo andor, 
representada pelo quadro da Primeira Missa no Brasil, e entraram em contato com os indígenas brasileiros, no terceiro andor, representados pela piroga. Vistos nesta ordem, os três blocos formam uma imagem narrativa em cujo centro está a Igreja.

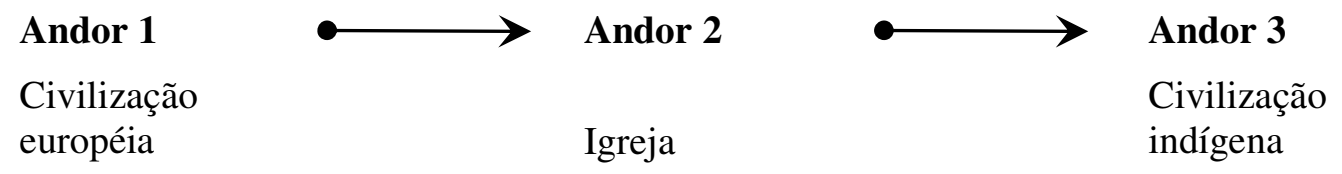

A igreja também foi representada no escudo luso-brasileiro, em que as cores de Portugal são unidas às do Brasil pela cruz vermelha. Era a cruz que mediava a união das cores. Chama a atenção que somente este bloco portava insígnias religiosas: o Estandarte da Humanidade, que bem poderia ser confundido com a imagem de uma santa ou de Maria com Jesus ao colo, e a cruz com a reprodução do quadro da Primeira Missa.

À primeira vista parece contraditório que a IPB se utilizasse de imagens religiosas, aparentemente católicas, para veicular a mensagem de que era intermediadora, não só das duas civilizações, mas também da passagem para a República, se considerarmos a analogia referida anteriormente. Mas deve-se entender a posição da IPB diante da Igreja Católica. Estes positivistas não eram anticlericais; eram contra o fato de ainda não haver na República a total separação entre a Igreja e o Estado. Eles admiravam, por exemplo, o papel da Igreja Católica durante a Idade Média e o poder espiritual que esta exercia sobre a sociedade. $\mathrm{O}$ objetivo da simbologia religiosa neste bloco era mobilizar os sentimentos dos cidadãos. Neste momento em que o Brasil era bastante católico, ainda era necessário fazer uso de um mimetismo religioso e se valer dos mesmos mecanismos de mobilização emocional que a Igreja Católica vinha utilizando com êxito, segundo os membros da IPB, desde a Primeira Missa. O que de fato os positivistas visavam era que a população vivenciasse um ato político com base no culto religioso. Era a experimentação de uma religião cívica. A missa e a festa já haviam sido apontadas por Comte como eventos de grande potencialidade ao positivismo.

O destaque à Igreja na procissão cívica, a ausência de um busto que colocasse Cabral em evidência ou a pertinência de um busto a Colombo não foram temas questionados pela imprensa. O único ponto discutido foi o 3 de maio como data do 
descobrimento do Brasil. O problema era que os jornais, ao publicarem históricos referentes ao descobrimento, citavam a data de 22 ou 23 de abril, e isso causava uma confusão com a data da comemoração do calendário. Os jornais O Paiz, Gazeta da Tarde e Jornal do Commércio não se referiram à confusão das datas. A Revista Ilustrada se eximiu de prestar uma explicação mais detalhada, apenas dava como fato que o governo havia adotado o 3 de maio como data oficial do descobrimento. O Diário de Notícias de 03 de maio explicou que o fato era devido à reforma do calendário gregoriano. Para o Diário do Commércio, a comemoração do descobrimento ficou naquele dia por uma questão de conveniência: o governo não queria que duas festas ficassem muito próximas, a de Tiradentes e a do descobrimento.

A Gazeta de Notícias, em editorial que ocupou sete das oito colunas da primeira página do jornal de 3 de maio, procurou explicar todas as etapas históricas do descobrimento do Brasil, destacando a carta de Pero Vaz de Caminha como evidência de que o Brasil havia sido descoberto em 23 de abril. Esclarece o artigo que a diferença das datas era por conta da adequação do calendário gregoriano e também por um costume político: José Bonifácio havia proposto que a abertura dos trabalhos constituintes em 1823 ocorresse em 3 de maio, em honra ao descobrimento do Brasil. O jornal criticamente conclui que, durante a Monarquia, esse dia foi atribuído ao descobrimento apenas por esse costume, e que fora o Governo Provisório que o transformara em data oficial no calendário. "Desde que é esta a lei, só nos resta acatarmo-la" ${ }^{32}$, concluíam resignados.

Os positivistas da IPB não se pronunciaram, neste momento, sobre a controvérsia das datas. Somente em 1899, por ocasião dos preparativos para comemorar o quarto centenário da descoberta, publicaram um texto explicativo, pois a polêmica efeméride novamente perturbava a lógica do calendário. $\mathrm{Na}$ explicação, os positivistas retomam as hipóteses dos jornais citados e refutam todas elas. Respondendo às acusações na imprensa de que eles haviam inventado esta incompreensível data, justificaram que foi colocada no projeto proposto a Demétrio Ribeiro porque o 3 de maio era o dia já arraigado na memória dos brasileiros para comemoração do descobrimento. Para eles, a descoberta se dera realmente em 22 de abril de 1500, porém, por um erro e pelos sentimentos religiosos da época, que aceitavam tradições sem questioná-las, a data do descobrimento foi associada à festa de Vera Cruz, que ocorria em 3 de maio, fazendo que os portugueses e depois os brasileiros consagrassem essa data como a da descoberta. Diferentemente do que é dito a respeito dos positivistas, vê- 
se aqui que tiveram uma posição flexível a respeito das datas e fatos históricos. Para eles, valia mais manter a eficácia emocional da comemoração, como costumavam fazer os antepassados, do que trocar a data para 22 de abril. O contrário, concluíram, "seria romper essa precioza comunhão com o conjunto das gerações tranzactas, justamente em uma ocazião [1890] em que mais preciso se tornava assegurar por todos os modos essa continuidade moral e social". ${ }^{33}$

Para compreender a participação dos positivistas na organização da festa de 03 de maio, é necessário ainda discutir a construção visual da mesma. Não foi encontrada documentação específica sobre o busto de Colombo ou das demais imagens, apenas a informação de que todas as obras empregadas na festa de 03 de maio eram de Villares.

Um inventário do acervo da IPB revelou um grande investimento em bustos, muito maior do que em estatuetas e quadros, grande parte dessas obras feitas por Villares. A ênfase visual dada às celebrações positivistas requeria objetos artísticos de uso flexível, como os bustos em gesso, que eram leves e permitiam que fossem pintados, dando maior realismo à imagem. O Templo da Humanidade, no Rio de Janeiro, foi decorado com bustos dos homenageados dos meses do calendário positivista. Também era uma prática da época utilizar bustos não só para serem instalados sobre hermas em praças, como para serem colocados em colunas, decorando salas públicas; e Villares teve algumas encomendas de bustos para esse fim.

Assim como o suporte, a temática dos andores já havia sido representada por Villares em outras obras. As figuras pintadas ou as inscrições de nomes nos andores da festa de 3 de maio eram homenageados do calendário positivista. O nono mês do calendário, dedicado a Gutenberg, tem cada dia da semana relembrando os navegantes, liderados por Colombo.

Villares também havia desenvolvido obras na temática indígena, logo que voltara de seus estudos de arte em Paris. Junto com Aurélio de Figueiredo, fora contratado para pintar dezoito telas, todas representando índios Botocudos, para a Exposição Antropológica de 1882, realizada no Museu Nacional (Nascimento, 1991). Anos adiante, Eduardo de Sá, outro artista positivista colaborador da IPB, retomaria o tema em quadros e no monumento a Floriano Peixoto, erguido na Cinelândia, no Rio de Janeiro. Essa era uma abordagem cara aos positivistas, porque permitia duas teses: a da formação da "raça brasileira", somatório de indígenas, portugueses e africanos, contra 
os projetos imigrantistas; e da solidariedade entre os povos sul-americanos, por sua origem indígena comum, contra as guerras entre as nações.

O quadro A Primeira Missa é especial aos positivistas também pelas representações indígenas; para eles, Victor Meirelles havia escolhido com sensibilidade posições compatíveis com o pudor, mesmo tendo de apresentá-los nus (Mendes, 1925, p.64, nota 23). Na "disputa" pela preferência aos quadros de batalhas de Victor Meirelles e de Pedro Américo, os positivistas entendiam que o primeiro fora menos cruel em mostrar as cenas de guerra. Mas é pela solenidade cultual que A Primeira Missa ganhou reconhecimento do grupo da IPB. A Religião, mesmo não sendo a da Humanidade, era a mediadora social, na representação de Meirelles.

$* * *$

Tentou-se neste texto analisar a festa como uma forma de construção visual, em que se têm os objetos que integram os andores, com seus significados, e também uma imagem do conjunto dos andores, criando uma nova narrativa. É necessário que outras festas sejam analisadas como construções visuais, para compararmos com a de 3 de maio e, com isso, sabermos o quão diferente, ou não, ela foi. Se foi, se ela pode ser exemplo de uma genuína celebração positivista, ou se apenas reproduziu a fórmula das festas cívicas da época.

Procurou-se mostrar como se compõe o culto positivista, destacando as atividades cívicas, e como o grupo brasileiro esteve envolvido na definição de um calendário de festas nacionais. Para este, a principal intervenção política necessária nos anos de 1880, visando a República, era o caráter cultual cívico. Propor um calendário de festas oficiais a um membro do Governo Provisório que demonstrava simpatias ao positivismo se tornou a grande oportunidade dos positivistas de consolidar este culto cívico.

Viu-se que, nos anos que antecederam a República, os positivistas promoveram várias atividades abertas ao público, tentando estabelecer um culto patriótico, porém com pouco sucesso de público. Desde esse período, a IPB vinha compondo sua coleção artística, cujas obras davam entrada no acervo em razão de celebrações cívicas, porque, também para os positivistas, não há culto sem contemplação de imagens.

Com a República instituída, os positivistas passaram, por um curto período, a participar das celebrações do calendário junto com outros grupos. Mas a festa de 3 de 
maio de 1890, ao que tudo indica, dirigida por eles, foi sua experiência de maior extensão nas celebrações públicas. Tendo um artista que não só aceitava a doutrina positivista, mas também tinha experiência profissional adequada para executar as imagens que comporiam o discurso histórico do descobrimento, e se valendo das relações pessoais com os militares da comissão oficial organizadora do evento, a IPB conseguiu, enfim, fazer seu grande evento - uma parada cívica com três andores principais, que se uniam em um discurso sobre o encontro das civilizações americana e européia, com a mediação da religião. Se, para o público, não era evidente de que religião se tratava, se católica ou da humanidade, não importava. Se, para a imprensa, o homenageado fora Cabral, mesmo que o busto sobre o andor fosse o de Colombo, também não era relevante. Para os positivistas, valia mais a comunhão cívica do que a verdade rigorosa dos fatos, o que também ficou evidente na manutenção da data do descobrimento em 3 de maio. Ambas as atitudes foram pouco ortodoxas para positivistas ortodoxos.

\section{REFERÊNCIAS BIBLIOGRÁFICAS:}

AGULHON, Maurice. Histoire Vagabonde I - Ethnologie et politique dans la France contemporaine. Paris: Gallimard, s/d.

ALBUQUERQUE, W. R. de. Algazarra nas ruas: comemorações da Independência na Bahia (1889-1923). Campinas: Ed. da Unicamp/Cecult, 1999.

CARVALHO, J. M. A Formação das Almas. São Paulo: Cia. das Letras, 1990.

CASTRO, C. Os militares e a República. Rio de Janeiro: Jorge Zahar, 1995.

CATROGA, Fernando. Ritualizações da História. In: História da História de Portugal. Lisboa: Temas e Debates, 1998.

FERREIRA NETO, E. L. O improviso da civilização: a nação republicana e a construção da ordem social no final do século XIX. Niterói, 1989. Dissertação (Mestrado em História) - ICHF, UFF.

GRANGE, J. La religion positive. In: La Philosophie d'Auguste Comte: science, politique, religion. Paris: PUF, 1996.

Rôle social de l'arte e art social. In: Auguste Comte - la politique et la science. Paris: Odile Jacob, 2000. 
JANCSÓ, I. Brasil formação do Estado Nação. São Paulo/Ijuí: Hucitec/Fapesp; Ed. Unijuí, 2003.

JANCSÓ, I.; KANTOR, I. Festa: cultura e sociabilidade na América portuguesa. São Paulo: Edusp/Hucitec, 2001.

KRAAY, H. "Frio como a pedra que se há de compor": caboclos e monumentos na comemoração da Independência na Bahia. Tempo: Revista do Departamento de História da UFF, Rio de Janeiro, n. 14, 2003.

LEAL, E. da C. Filósofos em Tintas e Bronze: arte, positivismo e política na obra de Décio Villares e Eduardo de Sá. Rio de Janeiro, 2006. Tese (Doutorado em História Social) - IFCS, UFRJ.

LEAL, E.; PEZAT, P. R. Capela Positivista de Porto Alegre: acervo bibliográfico, documental e iconográfico. Porto Alegre: SMC/Fumproarte; PPG/História-UFRGS, 1996.

LEMOS, M. O calendário pozitivista e o sr. Ministro da Fazenda. Rio de Janeiro: IPB, 1890.

O Apostolado Pozitivista do Brazil - Décima Circular Anual - 1890. Rio de Janeiro: IPB, 1892.

Artigos Epizódicos - quinta série - defeza dos feriados nacionais. Rio de Janeiro: IPB, 1894.

LEMOS, M. A questão do dia 03 de Maio como data do descobrimento do Brazil. In: Boletim do Apostolado Pozitivista do Brazil. n.13, 6 de junho de 1899.

. L'Apostolat Pozitiviste au Brésil - Deuxiéme Circulaire Annuelle - 1882. Rio de Janeiro: IPB, 1908.

.Resumo histórico do movimento positivista no Brasil: Ano de 1881: Relatório anual enviado ao Diretor Supremo do Positivismo em Pariz. $2^{\text {a }}$ ed. Rio de Janeiro: IPB, 1981 (1.ed. 1881).

LEMOS, R. Benjamin Constant - vida e história. Rio de Janeiro: Topbooks, 1999.

LEMOS, M.; MENDES, R. T. Bazes de uma Constituição Política Ditatorial Federativa para a República Brazileira. 2.ed. Rio de Janeiro: IPB, 1934.

MENDES, T. Teoria Positiva do Calendário. Gazeta de Notícias. 29.03.1881.

MENDES, R. T. O escultor brasileiro Candido Caetano de Almeida Reis e as suas relações com a Igreja Positivista de Brasil. Rio de Janeiro: IPB, 1925.

. Rezumo cronológico da evolução do pozitivismo no Brazil. Rio de Janeiro:

IPB, 1930.

HISTÓRIA, SÃO PAULO, v. 25, n. 2, p. 64-93, 2006 
MICHAELIS: moderno dicionário da língua portuguesa. São Paulo: Melhoramentos, 1998.

MILLIET, M. A. Tiradentes: o corpo do herói. São Paulo, 1998. Tese (Doutorado em Arquitetura e Urbanismo) - FAU, USP.

NASCIMENTO, F. R. A imagem do índio na segunda metade do século XIX. Rio de Janeiro, 1991. Dissertação (Mestrado em História da Arte) - EBA/UFRJ.

PACHECO, R. A. P. O cidadão está nas ruas: representações e práticas acerca da cidadania republicana em Porto Alegre (1889-1991). Porto Alegre: Ed. da Universidade/UFRGS, 2001.

PEZAT, P. R. Augusto Comte e os fetichistas: estudo sobre as relações entre a Igreja Positivista do Brasil, o Partido Republicano Rio-Grandense e a política indigenista na República Velha. Porto Alegre, 1997. Dissertação (Mestrado em História) - IFCH, UFRGS.

SCHWARCZ, L. M. O Império das Festas e as festas do Império. In: As barbas do Imperador. $2^{\text {a }}$ ed. São Paulo: Cia. das Letras, 1998.

TINHORÃO, J. R. As Festas no Brasil Colonial. São Paulo: Editora 34, 2000.

TRINDADE, H. $O$ positivismo - teoria e prática. Porto Alegre: Editora da Universidade/UFRGS, 1999.

VELloso, M. P. Comê, Morá? Descobrimento, comemoração e nacionalidade nas revistas humorísticas ilustradas. Projeto História, São Paulo, n.20, 2000.

LEAL, Elisabete da Costa.. The Republican Calendar and the Civic Celebration of the Discovery of Brazil in 1890: versions of history and positivist activism. História, São Paulo, v. 25, n. 2, p. 64-93, 2006.

Abstract: The paper concerns about not only the involvement of Positivist Church of Brazil members and some allied politicians in proposing Decree 155-B from January 14, 1890, which has established the republican calendar of official holidays, but also their efforts to consolidate it in the political culture of the First Republic. This movement is exemplified through an analysis of the celebration of May 3, 1890, which was decreed a holiday in celebration of the discovery of Brazil.

Keywords: First Republic, Positivism, Civic Celebrations.

Artigo recebido em 9/2006. Aprovado em 11/2006. 


\section{NOTAS}

* Doutora pelo PPG de História Social da UFRJ. Vice-presidente da ANPUH, Núcleo do Rio Grande do Sul, gestão 2006-2008. Agradeço a gentileza da primeira leitura e crítica de Hendrik Kraay. Este texto, em um formato resumido, foi apresentado no Simpósio Temático Imagem e Cultura Visual, durante o Simpósio Nacional de História da ANPUH, ocorrido em Londrina em 2005. Agradeço as observações dos participantes do Simpósio Temático, em especial de Iara Lis Schiavinatto

${ }^{1}$ A primeira agremiação positivista formou-se em 1876 com Antônio Carlos de Oliveira Guimarães (presidente), Joaquim Ribeiro de Mendonça, Benjamin Constant Botelho de Magalhães, Álvaro Joaquim de Oliveira, Cristiano Batista Franco, Oscar de Araújo, Francisco Ribeiro de Mendonça e Roberto Trompowsky Leitão de Almeida. Neste primeiro momento, Miguel Lemos e Teixeira Mendes não participavam da associação, embora em seus escritos se incluam na lista dos fundadores da agremiação. Consolidando essa primeira iniciativa, fundaram, em 05 de setembro de 1878, a Sociedade Positivista do Rio de Janeiro, filiada à Sociedade Positivista de Paris, dirigida por Pierre Laffitte. A Sociedade brasileira tinha como presidente Joaquim Ribeiro de Mendonça. A dissolução desta Sociedade ocorreu em 1881 e deu origem ao Centro Positivista Brasileiro ou Igreja Positivista do Brasil, sob [ a ] presidência de Miguel Lemos, ainda seguindo as orientações de Pierre Laffitte, com quem romperiam dois anos depois. Sobre estas primeiras agremiações positivistas consultar: Mendes, 1930; Lemos, 1981; Lemos, 1999.

${ }^{2}$ Os periódicos pesquisados para este texto foram publicados no Rio de Janeiro durante o ano de 1889 e 1890 e são: Jornal do Commércio; Diário de Notícias; O Paiz; Diário do Commércio; Gazeta da Tarde; Gazeta de Notícias; e Revista Ilustrada.

${ }^{3}$ Estudo sobre a confecção de obras de arte por artistas positivistas para fins políticos foi feito pela autora em: Leal, 2006.

4 Uma amadurecida historiografia trata das festas cívicas coloniais discutindo, por exemplo, as aproximações e distanciamentos das cerimônias brasileiras em relação à matriz portuguesa, em texto de Cardoso; ou a existência de um fenômeno de "oportunismo lúdico", conforme analisa Tinhorão, para as festas coloniais brasileiras oficiais e religiosas, em que percebeu a presença de um acento profano nestas, devido à impossibilidade de controle popular nos eventos públicos. Nas festas durante a Monarquia, temse também uma rica discussão sobre o significado e formato dos eventos festivos, como a contribuição de Souza, que estudou algumas convenções ou tradições em um fenômeno marcado pela temporalidade efêmera, arte efêmera, como chama as festas da monarquia luso-brasileira. Ela também analisa como a festa se substancia na imagem e é mediada por ela - pois a festa consegue dar corporeidade às idéias; ou a análise de Schwarcz, que discute a presença no Brasil de um rico imaginário acerca das "várias realezas", permitindo a existência de "várias festas", não no sentido numérico, mas no discursivo. Cardoso in Jancsó, 2003, p.549-601; Tinhorão, 2000, p.7-9; Souza, in Jancsó \& Kantor, p.545-66.; Schwarcz, 1998, p.247-94.

${ }_{5}^{5}$ Parte dos estudos sobre a Religião da Humanidade foram desenvolvidos quando, em 1996, organizei juntamente com o historiador Paulo Pezat o acervo da Capela Positivista de Porto Alegre. Nesse trabalho, foi possível fazer um arrolamento completo de todas as publicações da Igreja Positivista, aquelas editadas oficialmente pela instituição no Rio de Janeiro, em Porto Alegre e em Paris. Esse arrolamento foi publicado em: Leal \& Pezat, 1996.

${ }^{6}$ Sobre as atividades de educação operária desenvolvida por Comte e seus discípulos franceses, ver: Benoit, 1999.

${ }^{7}$ Decreto $^{\text {o. }} 155$ B, de 14 de janeiro de 1890.

${ }^{8} \mathrm{O}$ calendário proposto por Comte, elaborado para substituir o gregoriano, salienta os ciclos marcantes da evolução da humanidade e os representantes mais destacados, que deveriam ser consagrados por serem os exemplares da raça humana. Ele estabeleceu um calendário que chamou de concreto, pois baseou-se em seres reais, que pertencem à humanidade e que contribuíram para sua evolução. Os escolhidos não eram fixos, podendo ser substituídos com o tempo e as necessidades locais de novos heróis, mais nacionais. Para cada ciclo, representado por um mês com 28 dias, havia um homenageado. Cada semana, com sete dias, havia um representante hierarquicamente inferior ao do mês, e cada dia tinha outro representante hierarquicamente inferior ao da semana.

${ }^{9}$ Decreto $\mathrm{n}^{\mathrm{o} .}$ 03, de 28 de fevereiro de 1891.

${ }^{10}$ Lemos, 1894. Texto também publicado no Jornal de Commércio, 25 de agosto e 14 de outubro de 1892.

${ }^{11}$ O busto de Camões ficou na Biblioteca Nacional até 1924. Após grande disputa com o então diretor da Biblioteca, e por ordem do Ministro da Justiça e Negócios do Interior, atendendo a um requerimento dos positivistas, foi entregue à IPB e transladado para o Templo da Humanidade. 
${ }^{12}$ Curiosamente os positivistas ingleses realizavam anualmente a Festa das Máquinas, mas a direção da IPB, ao divulgar o evento, alertava que o Brasil não havia chegado ainda no estágio industrial, portanto não poderia realizá-la no país.

${ }^{13}$ Circular acerca da festa nacional de 7 de setembro de 1881 (in Lemos, 1981, p.72).

${ }^{14}$ Jornal do Commércio, 14 de julho de 1883, p.4.

${ }^{15}$ Sobre esta festa a Tiradentes ver: Carvalho, 1990; Milliet, 1998, cap.II; e Ferreira Neto, 1989.

16 Villares ingressou na Academia Imperial de Belas Artes em 1868. Abandonou-a após dois anos de estudos e partiu em 1872 para estudar arte em Paris, freqüentando o atelier de Alexandre Cabanel. Sua formação artística foi acadêmica, de influência sobretudo neoclássica como a da maioria dos estudantes de arte no Brasil, naquela época. Em Paris, conheceu Miguel Lemos, que lhe "apresentou" a doutrina positivista. Quando voltou ao Brasil em 1881, reencontrou um antigo colega do Colégio Pedro II Teixeira Mendes. Esses encontros reafirmaram os laços com os diretores da IPB e lhe garantiram o posto de pintor e escultor oficial da mesma, ornamentando os templos no Rio de Janeiro, em Porto Alegre e em Paris. O artista morreu em 1931, no Rio de Janeiro.

${ }^{17}$ Jornal do Commércio, 03 de maio de 1890, p.2.

18 Sobre os alunos de Benjamin Constant na Escola Militar da Praia Vermelha, ver: Castro, 1995 e Lemos, 1999.

19 Rostral significa "coluna ornada de proas de navios, elevada em memória de uma vitória naval" (Michaelis, 1998, p.1862).

${ }^{20}$ Almadia ou piroga são embarcações estreitas e compridas feitas de um tronco de árvore, usadas com remo ou vela (Michaelis, 1998, p.109).

${ }^{21}$ Gazeta de Notícias, 04 de maio de 1890, p.1.

${ }^{22}$ Gazeta da Tarde, 04 de maio de 1890, p.1.

${ }^{23}$ Diário de Notícias, 03 de maio de 1890, p.1.

${ }^{24}$ Gazeta de Notícias, 04 de maio de 1890, p.1.

${ }^{25}$ Diário de Notícias, 03 de maio de 1890, p.1.

${ }^{26}$ Revista Ilustrada, 03 de maio de 1890, p.2.

${ }^{27}$ O Paiz, 03 de maio de 1890, p.1.

${ }^{28}$ Diário de Notícias, 04 de maio de 1890, p.1.

${ }^{29}$ Sobre a política indigenista republicana e a posição dos positivistas da Igreja, ver: Pezat, 1997.

${ }^{30}$ Diário de Notícias, 03 de maio de 1890, p.1.

${ }^{31}$ Revista Ilustrada, 03 de maio de 1890, s/p.

${ }^{32}$ Gazeta de Notícias, 03 de maio de 1890, p.1. Editorial.

${ }^{33}$ Lemos, 1899. Também publicado no Jornal do Commércio, 27 de maio de 1899. 